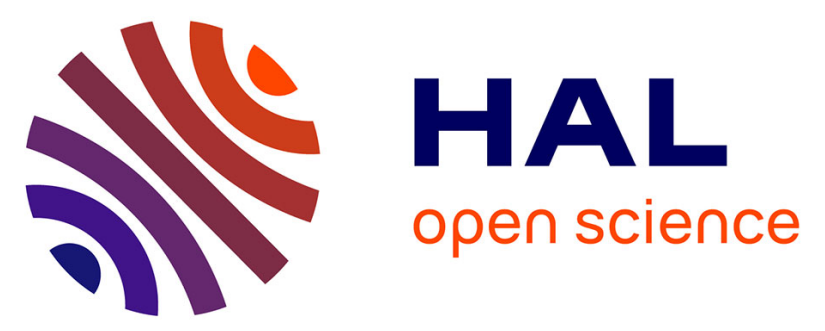

\title{
Efficient Electrochemical CO2/CO Interconversion by an Engineered Carbon Monoxide Dehydrogenase on a Gas-Diffusion Carbon Nanotube-Based Bioelectrode
}

Umberto Contaldo, Guigliarelli Bruno, Julien Pérard, Clara Rinaldi, Alan Le Goff, Christine Cavazza

\section{To cite this version:}

Umberto Contaldo, Guigliarelli Bruno, Julien Pérard, Clara Rinaldi, Alan Le Goff, et al.. Efficient Electrochemical CO2/CO Interconversion by an Engineered Carbon Monoxide Dehydrogenase on a Gas-Diffusion Carbon Nanotube-Based Bioelectrode. ACS Catalysis, 2021, 11 (9), pp.5808-5817. 10.1021/acscatal.0c05437 . hal-03258521

\section{HAL Id: hal-03258521 https://hal.science/hal-03258521}

Submitted on 22 Nov 2021

HAL is a multi-disciplinary open access archive for the deposit and dissemination of scientific research documents, whether they are published or not. The documents may come from teaching and research institutions in France or abroad, or from public or private research centers.
L'archive ouverte pluridisciplinaire HAL, est destinée au dépôt et à la diffusion de documents scientifiques de niveau recherche, publiés ou non, émanant des établissements d'enseignement et de recherche français ou étrangers, des laboratoires publics ou privés. 


\title{
Efficient electrochemical $\mathrm{CO}_{2} / \mathrm{CO}$ interconversion by an engi- neered carbon monoxide dehydrogenase on a gas-diffusion carbon nanotube-based bioelectrode
}

\author{
Umberto Contaldo ${ }^{1,2}$, Bruno Guigliarelli ${ }^{3}$, Julien Perard ${ }^{1}$, Clara Rinaldi ${ }^{1}$, Alan Le Goff ${ }^{2 *}$ and Christine \\ Cavazza $^{1 *}$
}

${ }^{1}$ Univ. Grenoble Alpes, CEA, CNRS, IRIG, CBM, F-38000 Grenoble, France

${ }^{2}$ University Grenoble Alpes, DCM UMR 5250, BEA, F-38000, Grenoble, France

${ }^{3}$ Aix Marseille Univ., CNRS, BIP UMR 7281, F-13009, Marseille, France.

KEYWORDS: Nickel enzymes, carbon monoxide dehydrogenase, carbon nanotubes, bioelectrocatalysis, $\mathrm{CO}_{2} \mathrm{RR}, \mathrm{EPR}$.

\begin{abstract}
Carbon monoxide dehydrogenase reversibly catalyzes the oxidation of $\mathrm{CO}$ into $\mathrm{CO}_{2}$. The monofunctional enzyme from Rhodospirillum rubrum $(\mathrm{Rr} \mathrm{CODH})$ has been extensively characterized in the past, although its use and investigation by bioelectrochemistry have been limited. Here, we developed a heterologous system yielding a highly stable and active recombinant $R r C O D H$ in one-step purification, with a CO oxidation activity reaching a maximum of $26,500 \mathrm{U} \mathrm{mg}^{-1}$, making $R r C O D H$ the most active CODH under ambient conditions described so far. Electron Paramagnetic Resonance was used to precisely characterize the recombinant $\mathrm{RrCODH}$, demonstrating the integrity of the active site. Selective $\mathrm{CO}_{2} / \mathrm{CO}$ interconversion with maximum turnover frequencies of $150 \mathrm{~s}^{-1}$ for $\mathrm{CO}$ oxidation $\left(1.5 \mathrm{~mA} \mathrm{~cm}{ }^{-2}\right.$ at $250 \mathrm{mV}$ overpotential $)$ and $420 \mathrm{~s}^{-1}$ for $\mathrm{CO}_{2}$ reduction $\left(4.2 \mathrm{~mA} \mathrm{~cm}{ }^{-2}\right.$ at $180 \mathrm{mV}$ overpotential) are catalyzed by the recombinant $\mathrm{RrCODH}$ immobilized on MWCNT electrodes modified with 1-pyrenebutyric acid adamantyl amide (MWCNT ${ }^{\mathrm{ADA}}$ ), either in classic three-electrode cell or in specifically-designed $\mathrm{CO}_{2} / \mathrm{CO}_{-}$diffusing electrodes. This functional device is stable for hours, and for at least 800,000 turnover numbers. The performances of recombinant $\mathrm{RrCODH}-\mathrm{modified}$ $\mathrm{MWCNT}^{\mathrm{ADA}}$ are closed to the best metal-based and molecular-based catalysts. These results greatly increase the benchmark for bioelectrocatalysis of reversible $\mathrm{CO}_{2}$ conversion.
\end{abstract}

\section{Introduction}

Ni-dependent carbon monoxide dehydrogenase ( $\mathrm{CODH})$ plays a central role in carbon metabolism in anaerobic microorganisms by reversibly catalysing the oxidation of $\mathrm{CO}$ into $\mathrm{CO}_{2}$ for a variety of metabolic purposes. It is able to produce $\mathrm{CO}$ from $\mathrm{CO}_{2}$ to synthesize diverse products (ethanol, acetate, methane, formate, ...). In the reverse direction, the enzyme catalyzes the oxidation of $\mathrm{CO}$ into $\mathrm{CO}_{2}, \mathrm{CO}$ serving thus as source of energy and fixed carbon. Enzyme performances result from billion years of evolution and selection, giving highly efficient catalysts with high substrate and function specificity in response to environmental demands. In the case of $\mathrm{CODH}$, the enzyme evolved as the most proficient catalyst in term of activity, selectivity and ability to operate at mild conditions with $\mathrm{CO}$ and $\mathrm{CO}_{2}$, known to be difficult to activate. X-ray structures of $\mathrm{CODH}$ from $R$. rubrum (RrCODH) and CODH-II from Carboxydothermus hydrogenoformans (ChCODH-II) both revealed a homodimer conformation with one active site per monomer, namely C-cluster. ${ }^{1,2}$ Three additional FeS clusters per dimer (2 $\mathrm{B}$-clusters and 1 intermolecular D-cluster) are present, the Bclusters mediating electron transfer between the active site and the protein surface. The C-cluster, unique in biology, is constituted of a $\mathrm{Fe}_{3} \mathrm{~S}_{4} \mathrm{Ni}$ cluster, linked to a mononuclear Fe site $(\mathrm{Fe} 1)$. Four different oxidation states have been proposed for C-clus- ter: a catalytically inactive and EPR-silent $\mathrm{C}_{\mathrm{ox}}$ state; a one-electron reduced $\mathrm{C}_{\text {red1 }}$ state, which binds $\mathrm{CO}$, a two-electron-reduced EPR-silent $\mathrm{C}_{\text {int }}$ intermediate state; and a three-electron-

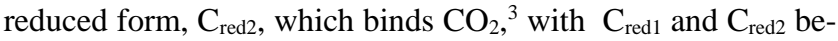
ing the two catalytically important oxidation states (Scheme 1). ${ }^{4}$

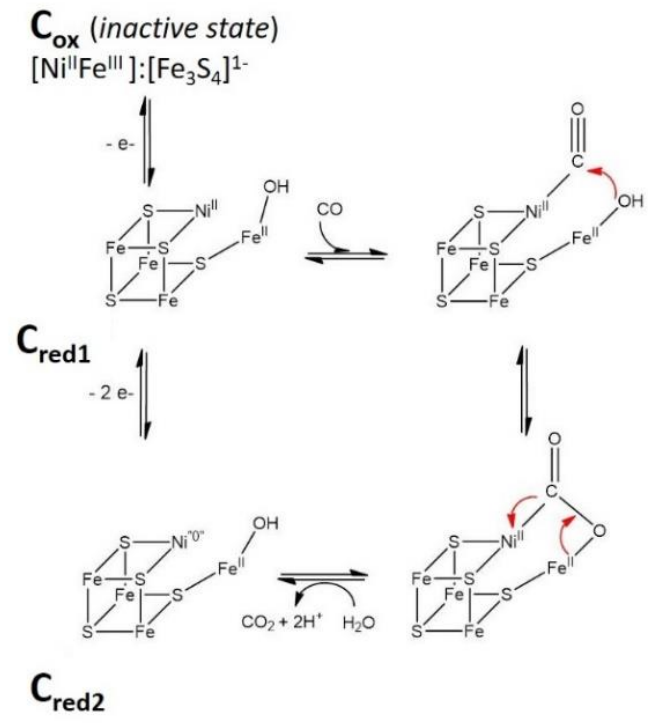

Scheme 1: Proposed mechanism of action of Ni-dependent CODH. 
The reaction mechanism of $\mathrm{CODH}$ has been extensively studied in the past decades and even if details are still discussed, ${ }^{5}$ this allowed to propose a common mechanistic model, postulating that $\mathrm{CO}$ binds to nickel and $\mathrm{H}_{2} \mathrm{O}$ to $\mathrm{Fe} 1$. After deprotonation of water, a nucleophilic attack of $\mathrm{OH}^{-}$on $\mathrm{CO}$ gives a $\mathrm{Fe} 1-\mathrm{Ni}$-bridging $\mathrm{COOH}$ intermediate. A second deprotonation yields a $\mathrm{Fe} 1-$ $\mathrm{Ni}$-bridging $\mathrm{COO}^{-}$species, before the release of $\mathrm{CO}_{2}$ and the reduction of the cluster by two electrons (Scheme 1). Electrons are subsequently transferred to an external electron acceptor via $\mathrm{Fe}_{4} \mathrm{~S}_{4}$ clusters. CODHs are mostly inactive at redox potentials higher than $-300 \mathrm{mV}$ vs. SHE. ${ }^{3}$ The $\mathrm{C}_{\mathrm{ox}} / \mathrm{C}_{\text {red } 1}$ redox couple and the $\mathrm{C}_{\text {red1 }} / \mathrm{C}_{\text {red2 }}$ redox couple potential were reported to be -200 $\mathrm{mV}$ and $-530 \mathrm{mV}$, respectively, the latter matching well with $\mathrm{CO} / \mathrm{CO}_{2}$ redox potential.

In the field of catalysis for sustainable chemistry, interest in $\mathrm{CODH}$ has dramatically increased in recent years in order to develop new methods for $\mathrm{CO}_{2}$ sequestration. $\mathrm{CODH}$ direct bioelectrochemistry has been deeply investigated by protein film voltammetry by Armstrong et a ${ }^{6,7,8,9}$ or Léger et al, ${ }^{10,11,12}$, showing the ability of these enzymes to behave as reversible electrocatalysts and catalyze selective $\mathrm{CO}$ oxidation and $\mathrm{CO}_{2}$ reduction with minimal overpotential. As in other types of metalloenzymes, this ability is achieved owing to low reorganization energies through multiple electron transfer, proton-coupled electron transfer and close values for redox potentials of the active site and the $\mathrm{CO}_{2} / \mathrm{CO}$ couple. Several attempts have also been made to integrate $\mathrm{CODH}$ in functional devices. When immobilized at silver-nanoparticle-coated $\mathrm{TiO}_{2}$ surfaces, $\mathrm{CODH}$ achieves fast photocatalytic $\mathrm{CO}_{2}$-to- $\mathrm{CO}$ reduction. ${ }^{13}$ Their mixing with graphite pellets along with the hydrogenase Hyd-2 from Escherichia coli allows the achievement of an enzymatic Water-Gas Shift Reaction (WGSR). ${ }^{14}$ However, the achievement of stable and high electrocatalytic activity towards $\mathrm{CO}_{2} / \mathrm{CO}$ interconversion has never been optimized in these systems, both in terms of CODH activity and interfacing with nanomaterials.

Despite the undeniable performances and specificities of CODH, several challenges must still be addressed to make their exploitation practical. Firstly, microorganisms that naturally produce this complex enzyme often require specific growth conditions (anaerobiosis, specific substrates and media, toxic gases, .....) ${ }^{15,16}$ Secondly, given its complexity, the biosynthesis and insertion of the multimetallic active sites into the target enzyme is extremely challenging. It requires the identification of all the protein partners involved in the intracellular metal trafficking and maturation machinery, as well as the understanding of the synchronization and the sequence of the different events leading to the biosynthesis of the active enzyme. ${ }^{17}$ Thirdly, while in nature, enzymes are spatially and temporally controlled by intracellular conditions and physiological partners, once purified and isolated, they become more sensitive to their environment ( $\mathrm{pH}$, temperature, oxygen, solvents, ...). In order to consider the relevance of complex redox metalloenzymes such as $\mathrm{CODH}$ for future biotechnological applications, the development of easy methods for their large-scale production is necessary. The possibility to produce $\mathrm{CODH}$ in easy-to-grow bacteria facilitates also mechanistic studies at the molecular level.

In the last decades, $C$. hydrogenoformans has represented a model organism for the study of monofunctional CODH.This thermophilic bacterium, able to use $\mathrm{CO}$ as a sole energy and carbon source, possesses four CODH (I to IV) with distinct functions. ${ }^{18}$ Among them, fully active recombinant monofunctional $C h C O D H-I I$ and -IV have been successfully purified from anaerobic $E$. coli cultures, ${ }^{19,10}$ and thoroughly structurally, electrochemically and spectroscopically characterized. However, in term of performances for potential future applications, the catalytic efficiencies of these thermophilic enzymes are limited under ambient conditions. On the other hand, CODH from the mesophile bacterium $R$. rubrum has been largely characterized since the late $80 \mathrm{~s},{ }^{20,21,22,23}$ although studies have been limited in the last decade. $R$. rubrum possesses a single monofunctional $\mathrm{CODH}$ (homologue to $C h \mathrm{CODH}-\mathrm{I}$ ), involved in the water gas shift reaction $\left(\mathrm{CO}+\mathrm{H}_{2} \mathrm{O} \rightarrow \mathrm{CO}_{2}+\mathrm{H}_{2}\right)$, enabling the bacterium to use $\mathrm{CO}$ as sole energy source. The reaction is catalyzed by a multiprotein complex involving $\mathrm{CODH}$, converting $\mathrm{CO}$ into $\mathrm{CO}_{2}$, a ferredoxin $\mathrm{CooF}$ transferring the electrons produced to an energy conserving-[NiFe]-hydrogenase $(\mathrm{ECH}) .{ }^{24}$ In $R$. rubrum, the structural gene of $\mathrm{CODH}$, namely $\operatorname{coos}$, belongs to the cooFSCTJ operon, where $c o o F$ encodes the ferredoxin CooF ${ }^{25} \operatorname{coo} C$ a Ni-dependent ATPase, ${ }^{26}$ and cooT and cooJ, two nickel chaperones. ${ }^{27,28,29,30}$ In vivo, the three chaperones $\mathrm{CooC}$, CooT and CooJ are required for the correct insertion of nickel into the active site, shown to be a key step in the enzyme activation. ${ }^{31,32}$

Wiring of metalloenzymes at electrodes requires rational strategies aimed at minimizing electrode-active site distances as well as maximizing catalyst loading. In this respect, carbon nanotubes (CNTs) possess a set of abilities which make them an ideal material for such purpose: thin nanowire morphology, biocompatibility, high conductivity, high electroactive surface and ease of functionalization. ${ }^{33,34,35,36}$ Furthermore, these biofunctionalized nanomaterials can be further integrated in operational devices such as gas-diffusion electrodes of fuel cells. ${ }^{34,36,37}$ Specific functionalization of CNTs has taken advantage of noncovalent interactions such as enzyme dipolar moment, or hydrophobic/hydrophilic interactions to enhance the immobilization of enzymes such as hydrogenases or laccases and influence their orientation at CNTs. ${ }^{33}$

In the present study, we developed a novel heterologous system allowing the easy production of highly active recombinant $\operatorname{RrCODH}(\mathrm{Rec}-\operatorname{RrCODH})$ in good yields which was biochemically and spectroscopically characterized in details. MultiWalled CNT (MWCNT) electrodes were modified with 1pyrenebutyric acid adamantyl amide in order to optimize Rec$\operatorname{RrCODH}$ direct electrochemistry as well as enzyme loading at electrodes for $\mathrm{CO} / \mathrm{CO}_{2}$ interconversion, either in classic threeelectrode cell or in specifically-designed $\mathrm{CO}_{2} / \mathrm{CO}$-diffusing electrodes.

\section{Results and Discussion Metallated RrCODH is produced in E.coli under aerobic con- ditions}

The structural gene of $\operatorname{RrCODH}(\operatorname{RrcooS})$ from Rhodospirillum rubrum was expressed in E. coli. Two forms of the recombinant enzyme were produced by transforming $E$. coli with either $\operatorname{cooS}$ alone or with the three $\operatorname{coo} C$, cooT and $\operatorname{cooJ}$ genes, yielding Rec- $R r C O D H$ and $\mathrm{Rec}-\operatorname{RrCODH}{ }^{\mathrm{CTJ}}$, respectively. One-step purification led to pure and homogeneous enzymes as shown by SDS-PAGE (Figure S1A). The two enzymes were routinely purified with a yield of 14 to $17 \mathrm{mg}$ of $\mathrm{Rec}-\mathrm{RrCODH}$ and 4 to 6 $\mathrm{mg}$ of Rec- $R r C O D H^{\mathrm{CTJ}}$ per liter of culture. SEC-MALLS-IR 
experiments show the homogeneity and the homodimeric organisation (Figure S1B).

In addition, both $\mathrm{CODH}$ displays the typical brown coloration due to the presence of $\mathrm{Fe}_{4} \mathrm{~S}_{4}$ clusters. This is also supported by the UV-visible absorption spectra of the oxidized enzymes. The typical broad shoulder from 350 to $480 \mathrm{~nm}$ (Figure S1C) and a purity coefficient (A420/A280) of 0.37-0.38 are comparable to that of wild-type $\operatorname{RrCODH} .^{38}$ Metal content determination on Rec- $\operatorname{RrCODH}$ and $\mathrm{Rec}-\operatorname{RrCODH}{ }^{\mathrm{CTJ}}$ revealed that iron content is similar in both enzymes with approximately 9-10 atoms of iron per monomer, in agreement with the expected $10 \mathrm{Fe}$ atoms per monomer found in the wild-type enzyme. As previously de scribed for the three CODH I, II \& IV from $C$. hydrogenoformans, ${ }^{39}{ }^{19}$ the ISC machinery from $E$. coli appears then to be able to build the B-and D-clusters and deliver the FeS moiety of the C-cluster in $R r C O D H$. In $R$. rubrum, the ISC machinery is not present but is likely replaced by the SUF machinery, ${ }^{40}$ suggesting that ISC and SUF machineries are interchangeable for $\mathrm{FeS}$ insertion into the $\mathrm{C}$-cluster.

Nickel content is about $0.7 \pm 0.1$ and $0.8 \pm 0.1$ of $\mathrm{Ni}$ (II) per monomer for Rec- $R r C O D H$ and $\mathrm{Rec}-\operatorname{RrCODH}{ }^{\mathrm{CTJ}}$, respectively corresponding to about 70 and $80 \%$ of the expected content in a fully metallated enzyme. Consequently, the supplementing of $500 \mu \mathrm{M}$ of $\mathrm{Ni}$ (II) salt to the growth medium seems to be sufficient to allow partial nickel insertion into $\mathrm{RrCODH}$ in cellulo, without the requirement of the three chaperone CooCTJ. It is in agreement with previous studies showing that a $\mathrm{Ni}$ excess can compensate for the absence of the chaperones. More surprisingly, aerated culture of $E$. coli in the absence of reducing agents except L-cysteine and Fe(II) salts would allow Ni insertion into RrCODH. This was not expected since the redox potential of $E$. coli cytoplasm is estimated to be about $-0.22 \mathrm{~V}$ while C-cluster biosynthesis and especially Ni insertion mechanism, has been shown to require a reducing step at low redox potential (below $-0.3 \mathrm{~V}$ ). Besides, the production of all active recombinant $\mathrm{CODH}$ produced in $E$. coli described so far require anaerobic conditions in the presence of highly reducing agents, such as sodium sulfide.

\section{CO oxidation activity of Rec-RrCODH and Rec-RrCODH ${ }^{C T J}$ in solution}

In order to determine their specific activity, the enzymes were first diluted in $50 \mathrm{mM}$ Tris- $\mathrm{HCl}$, $\mathrm{pH} 8.5,5 \mathrm{mM}$ DTT with dithionite (DTH) at $21^{\circ} \mathrm{C}$ prior to measurement. Interestingly, Rec$\mathrm{RrCODH}$ activity is strictly dependent on DTH concentration, the enzyme requiring a reducing pre-activation step by adding at least $15 \mathrm{mM}$ DTH to reach a maximum specific activity of $2,500 \mathrm{U} \cdot \mathrm{mg}^{-1}$ (Figure S2). In contrast, Rec- $R r \mathrm{CODH}^{\mathrm{CTJ}}$ does not require any reducing pre-activation and reach a specific activity of $10,508 \mathrm{U} \cdot \mathrm{mg}^{-1}$ in the presence of $1 \mathrm{mM}$ DTH (Table 1). Moreover, the latter enzyme remains active for several days at room temperature without the requirement of any additional reactivation $(91 \%$ of maximum specific activity after 140 hours). While the Fe and Ni contents are comparable in both enzymes, the co-production of Rec- $R r C \mathrm{CODH}$ with the three CooCTJ proteins seems to play a significant role on the stability and activity of the produced enzyme, although their role at the molecular level has been not yet elucidated. This is in agreement with previous studies on the CODH from Desulfovibrio vulgaris, highlighting the plasticity of the C-cluster and the identification of different reduced active or oxidized inactive $\mathrm{C}$ cluster states. ${ }^{45}$ Moreover, with a specific activity of 5,685 $\mathrm{U} \cdot \mathrm{mg}^{-1}$ at $\mathrm{pH} 7.5$ (corresponding to $75 \%$ of the native enzyme one purified from $R$. rubrum $^{41}$ ), $\mathrm{Rec}-\mathrm{Rr} \mathrm{CODH}^{\mathrm{CTJ}}$ appears roughly as active as the native enzyme (Table 1), considering a $\mathrm{Ni}$ content of about $0.8 \mathrm{Ni}$ atom per monomer. Therefore, we consider that the expression system developed in this study allows the production of a fully active and stable recombinant $\operatorname{Rr} \mathrm{CODH}$.

\begin{tabular}{|c|c|c|c|}
\hline & \multicolumn{3}{|c|}{$\begin{array}{c}\text { CO oxidation } \\
1 U: 1 \mu \mathrm{mol} \text { of } C O \text { oxidized } \cdot \mathrm{min}^{-1}\end{array}$} \\
\hline & $\mathrm{pH}$ & $\mathrm{T}\left({ }^{\circ} \mathrm{C}\right)$ & $\mathrm{U} \cdot \mathrm{mg}^{-1}$ \\
\hline Native $\operatorname{RrCODH}{ }^{41}$ & 7.5 & 25 & 7,700 \\
\hline Rec- $\operatorname{RrCODH}{ }^{\mathrm{CTJ}}$ & $\begin{array}{l}7.5 \\
8.5 \\
9.5\end{array}$ & $\begin{array}{l}25 \\
25 \\
50\end{array}$ & $\begin{array}{c}5,685 \\
\mathbf{1 0 , 5 0 8} \\
26,016\end{array}$ \\
\hline $\begin{array}{c}\text { Native } C h \mathrm{CODH}-\mathrm{I}^{42} \\
\text { Recombinant } C h \mathrm{CODH}-\mathrm{I}(+\mathrm{Ni}(\mathrm{II}) \& \mathrm{CooC})^{39}\end{array}$ & 8.0 & $\begin{array}{l}20 \\
70 \\
95 \\
70\end{array}$ & $\begin{array}{c}1,300 \\
15,756 \\
37,949 \\
8,060\end{array}$ \\
\hline $\begin{array}{c}\text { Native } C h \mathrm{CODH}-\mathrm{II}^{42} \\
\text { Recombinant } C h \mathrm{CODH}-\mathrm{II}(+\mathrm{Ni}(\mathrm{II}))^{19}\end{array}$ & 8.0 & $\begin{array}{c}20 \\
70 \\
105 \\
70\end{array}$ & $\begin{array}{l}1,000 \\
14,200 \\
40,666 \\
12,229\end{array}$ \\
\hline $\begin{array}{l}\text { Recombinant TspCODH-1 (+Ni(II) \& CooC })^{43} \\
\text { Recombinant TspCODH-2 (+Ni(II) \& CooC })^{43}\end{array}$ & 8.0 & 37 & $\begin{array}{c}62 \\
262\end{array}$ \\
\hline Recombinant $D v \mathrm{CODH}(+\mathrm{Ni}(\mathrm{II}) \& \mathrm{CooC})^{44}$ & 10.0 & 37 & 1,660 \\
\hline
\end{tabular}

Table 1. Specific activities of monofunctional CODH 
pH and temperature dependence of Rec-RrCODH ${ }^{C T J} \mathrm{CO}$ oxidation in solution

Several monofunctional CODH have been thoroughly characterized over the last decades. Although $\mathrm{CODH}$ from the thermophile $C$. hydrogenoformans have often been described as the most active enzymes, there are many discrepancies about optimum temperature and $\mathrm{pH}$ of $\mathrm{CODH}$ activity in the literature (Table 1). We therefore decided to perform a $\mathrm{pH}$ and temperature dependence study of $\mathrm{CO}$ oxidation activity displayed by Rec- $\operatorname{RrCODH}{ }^{\mathrm{CTJ}}$. First, the effect of $\mathrm{pH}$ and temperature on the kinetics was evaluated (Figure 1A,B). Second, the enzyme stability according to $\mathrm{pH}$ and temperature was measured (Figure 1C,D). We determined an optimum $\mathrm{pH}$ and temperature of 9.5 and $50^{\circ} \mathrm{C}$, respectively. Under these conditions, Rec$\operatorname{RrCODH}{ }^{\mathrm{CTJ}}$ reaches a CO oxidation activity of $26,016 \mathrm{U} \cdot \mathrm{mg}^{-1}$.
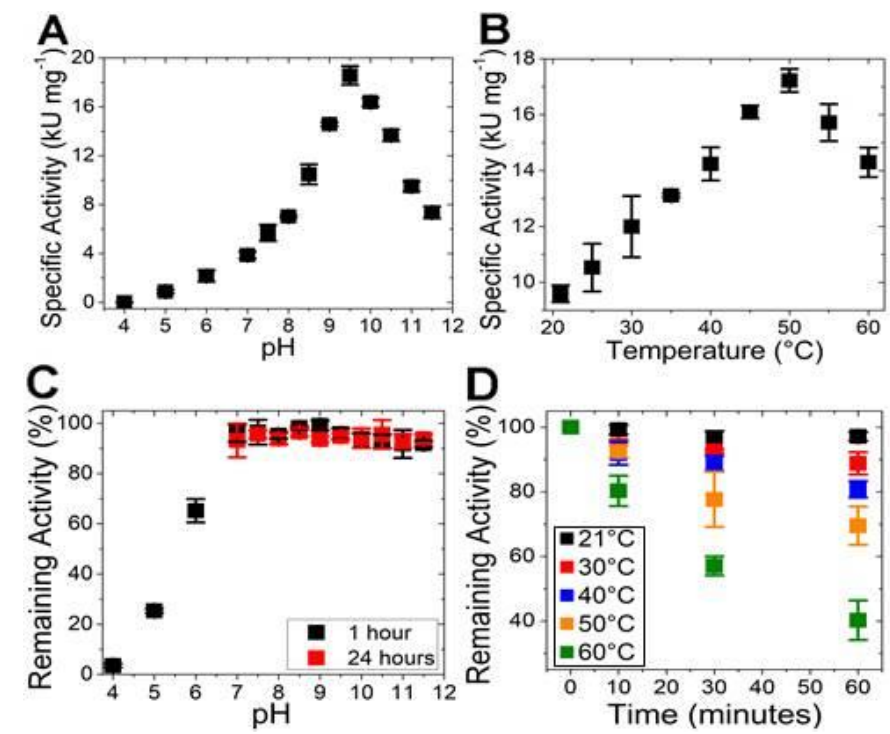

Figure 1. CO oxidation activity of Rec- $\operatorname{RrCODH}{ }^{\mathrm{CTJ}}$ in solution (4 $\mathrm{nM}$ dimer) $\mathrm{A}$ : $\mathrm{pH}$ titration from 4.0 to 11.5 , with a maximum activity of $18,567 \mathrm{U} \mathrm{mg}^{-1}$ reached at $\mathrm{pH} 9.5$ and $21^{\circ} \mathrm{C} \mathrm{B}$ : Temperature dependence from 21 to $60{ }^{\circ} \mathrm{C}$, with a maximum activity of 17,221 $\mathrm{U} \mathrm{mg}^{-1}$ reached at $50{ }^{\circ} \mathrm{C}, \mathrm{pH} 8.5 \mathrm{C}$ : $\mathrm{Rec}-\operatorname{RrCODH}{ }^{\mathrm{CTJ}}$ stability according to $\mathrm{pH} \mathbf{D}$ : $\mathrm{Rec}-\operatorname{Rr} \mathrm{CODH}^{\mathrm{CTJ}}$ stability according to temperature.

By comparison with other $\mathrm{CODH}$, we observed that $\mathrm{CO}$ oxidation activities of Rec- $R r C O D H^{C T J}$, Wild-type $C h C O D H-I$ and wild-type or recombinant $C h \mathrm{CODH}-\mathrm{II}$ are comparable at their optimum temperature $\left(50{ }^{\circ} \mathrm{C}\right.$ and $70^{\circ} \mathrm{C}$, respectively) (Table 1$)$. In contrast, recombinant, $\mathrm{CODH}$ from Desulfovibrio vulgaris (DvCODH), and recombinant CODH from Thermococcus $S p$. (TspCODH-1 and -2) are much less active (Table 1), suggesting that under these conditions, the enzyme may not be fully and correctly maturated. The low activity of recombinant $T s p$ CODH produced in Desulfovibrio (Table 1) strongly suggests that aside from $\mathrm{CooC}$, other missing partners are likely required for CODH maturation. In this latter case, we observed that two not annotated genes present downstream CooC2 actually encodes two CooT proteins. Their presence in a common cluster gene with $\operatorname{cooS}$ and $\operatorname{cooC}$ strongly suggest their implication in the $\mathrm{C}$-cluster biosynthesis. Another possibility would be that some $\mathrm{CODH}$ are not directly involved in $\mathrm{CO} / \mathrm{CO}_{2}$ interconversion catalysis but would have other functions, as illustrated by ChCODH-IV, a CO scavenger in defence against oxidative stress. $^{10}$ The different specific activities of recombinant $C h \mathrm{CODH}-\mathrm{I}$ and $C h \mathrm{CODH}-\mathrm{II}$ when produced in $E$. coli in the presence or absence of CooC and/or Ni salts (Table 1) also suggest fundamental differences in their maturation pathways and nickel-dependent enzyme activation. All these studies point out that the mechanism of nickel insertion into the C-cluster appears to be not straightforward and not common for all $\mathrm{CODH}$.

\section{EPR characterization of $\operatorname{Rec}-\mathrm{RrCODH} \mathrm{H}^{\mathrm{CTJ}}$}

To further examine and characterize the metal cluster integrity of Rec- $R r C O D H^{\mathrm{CTJ}}$, redox titration of the recombinant enzyme was performed and monitored by EPR spectroscopy at low temperature $(10 \mathrm{~K})$. After buffer exchange, the enzyme solution was prepared anaerobically in $100 \mathrm{mM}$ MOPS buffer $\mathrm{pH} 8.0$ and titrated in glove box with DTH.

Upon reduction of Rec-RrCODH ${ }^{\mathrm{CTJ}}$, no significant signal was observed above $-250 \mathrm{mV}$. Below this value, a rhombic signal develops at $\mathrm{g}=2.029,1.886$ and 1.710 (Figure 2A-a). This signal is characteristic of the $\mathrm{C}_{\text {red1 } 1}$ state of the C-cluster ${ }^{46,47}$ and reaches a maximum amplitude at about $-450 \mathrm{mV}$ (Figure $\mathrm{S} 3$ ). Concomitantly a second rhombic signal appears below $-350 \mathrm{mV}$ with $\mathrm{g}$ values at $2.041,1.931$ and 1.882 . This signal is typical of a reduced $[4 \mathrm{Fe}-4 \mathrm{~S}]^{1+}$ center and increase progressively upon reduction with a significant broadening below $-500 \mathrm{mV}$ and broad lateral bands around $\mathrm{g}=2.09$ (Figure 2A-c,d) likely due to intercluster magnetic couplings. ${ }^{48,49}$ Interestingly, below -500 $\mathrm{mV}$ the $\mathrm{C}_{\text {red1 }}$ signal decreases and additional features appear at $\mathrm{g}=1.757$ and 1.970 which reveals the redox conversion of the $\mathrm{C}_{\text {red1 }}$ state into the $\mathrm{C}_{\mathrm{red} 2}$ one $(\mathrm{g}=1.970,1.887 ; 1.757)$, a conversion reported as a two-electron redox process. ${ }^{47}$ All these signals exhibit fast relaxation properties typical of CODH metal centers, the FeS signal being not saturated at $10 \mathrm{~K}$ with $1 \mathrm{~mW}$ microwave power, while $\mathrm{C}_{\text {red } 1}$ and $\mathrm{C}_{\text {red2 }}$ are not saturated up to $10 \mathrm{~mW}$. Spin intensity measurements performed at $10 \mathrm{~K}$ by double integration of the EPR spectra recorded in non-saturating conditions indicate that $\mathrm{C}_{\text {red1 }}$ signal corresponds to 0.6 spin/dimer (0.3 spin/monomer) at its maximum intensity (around $-450 \mathrm{mV}$ ), and that the EPR spectrum of the most reduced sample represents 3.0 spins/dimer (1.5 spin/monomer). Although the $\mathrm{C}_{\text {red2 }}$ signal overlaps $\mathrm{FeS}$ and $\mathrm{C}_{\text {red1 }}$ signals, it has been possible to estimate its spin intensity by performing spectral differences between samples taken at different potentials. In the more reduced state of the enzyme it corresponds to 0.34 spin/dimer ( $0.17 \mathrm{spin} / \mathrm{monomer})$ suggesting that, within experimental error, all the $C_{\text {red1 }}$ state is converted into $C_{\text {red2 }}$ during redox titration. Moreover, by weighting the spin intensity of $\mathrm{C}_{\text {red1 }}$ and $\mathrm{C}_{\text {red2 }}$ signals by the amplitude of the lines at $\mathrm{g}=1.71$ and 1.757 , respectively, their contributions to the total spin intensity of each sample could be subtracted to deduced that of the FeS signal alone. 
A

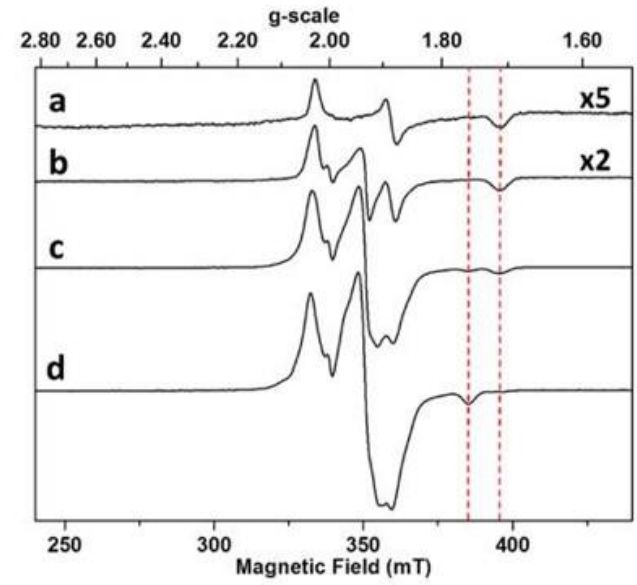

B

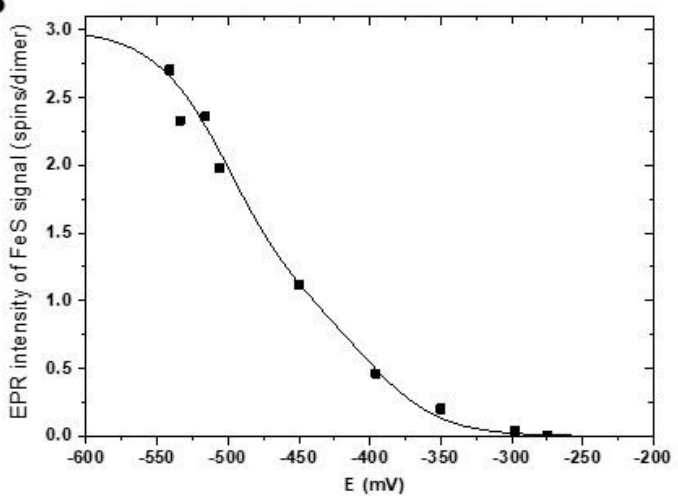

C

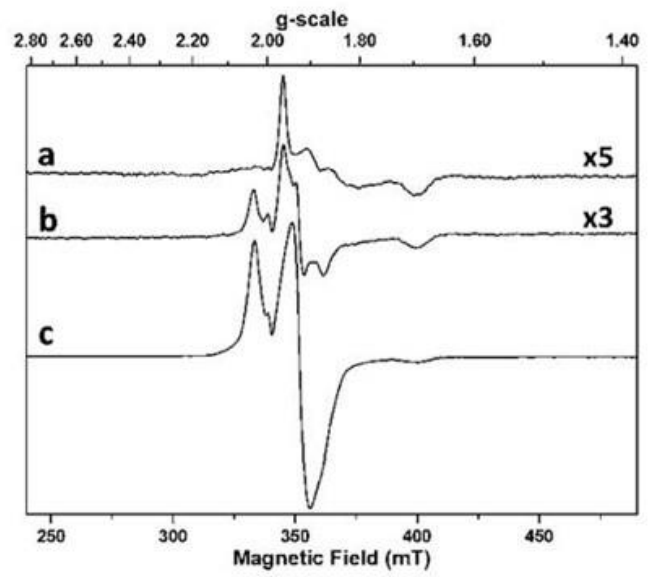

Figure 2. EPR titration of Rec- $R r \mathrm{CODH}^{\mathrm{CTJ}}$. A: EPR spectra of Rec$\operatorname{RrCODH}{ }^{\mathrm{CTJ}}$ poised at different potentials. a) $-275 \mathrm{mV}$, b) -396 $\mathrm{mV}$; c) $-506 \mathrm{mV}$; d) $-541 \mathrm{mV}$. Experimental conditions: temperature, $10 \mathrm{~K}$; microwave power, $10 \mathrm{~mW}$ at $9.480 \mathrm{GHz}$; modulation amplitude, $1 \mathrm{mT}$ at $100 \mathrm{kHz}$. Red vertical dashed lines indicate the

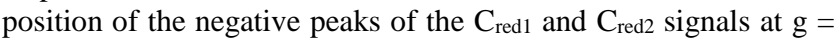
1.710 and 1.757 respectively. B: Redox behaviour of the FeS signal spin intensity. For each sample the spin intensity of the FeS signal (black squares) was obtained by subtracting the $\mathrm{C}_{\text {red1 } 1}$ and $\mathrm{C}_{\text {red2 }}$ signal contributions (see text). The curve is the sum of two Nernst processes centered at $\mathrm{E}^{\circ}{ }_{1}=-400 \mathrm{mV}$ and $\mathrm{E}_{2}^{\circ}=-500 \mathrm{mV}$ weighted by spin intensity one and two, respectively. EPR conditions as in panel A except microwave power $1 \mathrm{~mW}$. C: EPR titration of Rec$\operatorname{RrCODH}{ }^{\mathrm{CTJ}}$ in the presence of cyanide. a) $-297 \mathrm{mV}$; b) $-416 \mathrm{mV}$;

c) $-592 \mathrm{mV}$. EPR conditions as in panel A.
The redox behaviour of the FeS signal intensity so obtained is well fitted by the superimposition of two Nernst curve centered at $\mathrm{E}^{\circ}{ }_{1}=-400 \mathrm{mV}( \pm 10 \mathrm{mV})$ and $\mathrm{E}^{\circ}{ }_{2}=-500 \mathrm{mV}( \pm 10 \mathrm{mV})$, corresponding to one and two spins/dimer, respectively (Figure 2B). This result is in good agreement with the FeS cluster content of $\mathrm{RrCODH}$ dimer which is composed of one intermonomer bridging D-cluster and two B-clusters. All these results indicate clearly that the metal cofactor content and properties of the Rec- $\operatorname{RrCODH}{ }^{\mathrm{CTJ}}$ enzyme are similar to that of the native enzyme.

Cyanide is a well know inhibitor of $\mathrm{CODH}$ which binds directly on the catalytic $\mathrm{C}$-cluster of the enzyme. ${ }^{4}$ To address the ability of this inhibitor to interact with C-clusters of the Rec$R r \mathrm{CODH}^{\mathrm{CTJ}}$ enzyme, EPR titration of the enzyme was also performed anaerobically in the presence of an excess of $\mathrm{NaCN}$ ( 100 eq). Below $-250 \mathrm{mV}$ a complex EPR signal can be observed with a sharp peak at $\mathrm{g}=1.969$ and major features at $\mathrm{g}=$ $1.898,1.848$ and 1.70. Additionally, a broad line is also detected at high field around $\mathrm{g}=1.57$ (Figure $2 \mathrm{C}$-a). This signal is characterized by fast relaxation properties, being not saturated at 10 $\mathrm{K}, 10 \mathrm{~mW}$. This signal is reminiscent of other EPR signals obtained upon treatment of other $\mathrm{CODH}$ with cyanide. ${ }^{50}$ Upon more pronounced reduction its amplitude remains approximately unchanged, while the signatures of $\mathrm{FeS}$ center develop at $\mathrm{g}=2.039,1.932$ and 1.88 (Figure 2C-b).

At very low potential, the $\mathrm{FeS}$ signal is similar to that detected in absence of cyanide (Fig. 2C-c). In contrast to the titration without cyanide, no $\mathrm{C}_{\text {red1 }}$ or $\mathrm{C}_{\text {red} 2}$ signal was observed in the whole potential range investigated which confirms that the Rec$\operatorname{RrCODH}{ }^{\mathrm{CTJ}}$ is fully inhibited by cyanide as the native enzyme. In view of its characteristics, Rec- $R r C O D H^{C T J}$ appears in our opinion as the best compromise for future studies and applications, considering on the one hand its easy production and purification and on the other hand its high activity under ambient conditions (physiological $\mathrm{pH}$ and room temperature) and its stability (several months at $4^{\circ} \mathrm{C}$ ). These encouraging results urged us to investigate its electrocatalytic properties towards both $\mathrm{CO}$ oxidation and $\mathrm{CO}_{2}$ reduction in a specifically designed gas-diffusion enzymatic system

\section{Direct Electrochemistry of Rec-RrCODH.}

We have recently investigated the use of Direct Electron Transfer (DET) promoters for metalloenzymes in order to favour their immobilization and orientation at the surface of MWCNT electrode. The adamantane moiety have proven its ability to strongly interact with well-defined hydrophobic patches at the surface of several metalloenzymes such as laccase ${ }^{51}$ and $\mathrm{NiFeSe}$ hydrogenases. ${ }^{36}$ In this respect, Rec- $R r C O D H$ and Rec$\operatorname{RrCODH}{ }^{\mathrm{CTJ}}$ were immobilized at MWCNT electrodes modified with 1-Pyrenebutyric acid adamantyl amide. Electrochemistry of pristine MWCNT and adamantane-modified MWCNT $\left(\mathrm{MWCNT}^{\mathrm{ADA}}\right.$ ) were compared under $\mathrm{Ar}, \mathrm{CO}$ or $\mathrm{CO}_{2}$ after incubation of the electrode in a $38 \mu \mathrm{M}$ of monomer for 4 hours.

Figure 3 displays $\mathrm{CV}$ performed under argon at $\mathrm{pH} 8.5$ for MWCNT and MWCNT ${ }^{\mathrm{ADA}}$ electrodes. A reversible redox system is observed at $\mathrm{E}_{1 / 2}=-0.595 \mathrm{~V}$ vs. $\mathrm{SHE}(\mathrm{pH} 8.5)$ for both type of electrodes, corresponding to the $\mathrm{C}_{\text {red1 }} / \mathrm{C}_{\text {red2 }}$ redox system. A potential/ $\mathrm{pH}$ dependence was performed between $\mathrm{pH} 5.0$ and 9.5 . A $58.4 \mathrm{mV}$ slope per $\mathrm{pH}$ unit is consistent with a proton/electron ratio of 1 . Considering the fact that the observed 
redox potential is consistent with the redox potential of the $\mathrm{C}_{\text {red1 }} / \mathrm{C}_{\text {red2 }}$ redox system (see above), this $\mathrm{pH}$ dependence likely account for a two proton/two electron system. This is further confirmed by the value of the potential width of $\Delta \mathrm{E}_{\mathrm{p}, 1 / 2}=55 \mathrm{mV}$ at half-height, closed to the theoretical value of $90.6 / 2=45.3$ $\mathrm{mV}$ accounting for a surface-confined bielectronic system. ${ }^{52}$
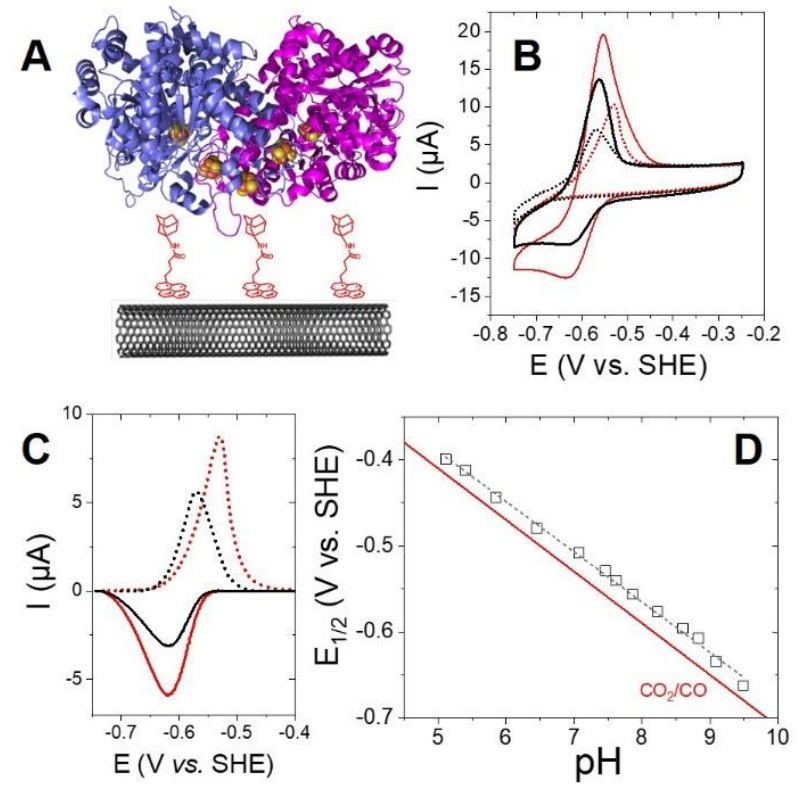

Figure 3. A: Schematic representation of CODH-modified MWCNT $^{\mathrm{ADA}}$. B: $\mathrm{CVs}$ of the Rec- $\operatorname{RrCODH}{ }^{\mathrm{CTJ}}$-functionalized (black) pristine MWCNT, (red) MWCNT ${ }^{\mathrm{ADA}}$ electrodes under Ar at $\mathrm{pH} 8.5$ before (straight line) and after (dotted line) addition of 2 $\mathrm{mM} \mathrm{NaCN}\left(50 \mathrm{mM}\right.$ Tris-HCl, $\mathrm{pH} 8.5, \mathrm{v}=5 \mathrm{mV} \mathrm{s}^{-1}$ ). C: Background-subtracted oxidation peak (in the presence of $\mathrm{NaCN}$ ) and reduction peak for $\mathrm{Rec}-\mathrm{Rr} \mathrm{CODH} \mathrm{CTJ}^{\mathrm{CT}}$-functionalized (black) pristine MWCNT, (red) MWCNT ${ }^{\mathrm{ADA}}$ electrodes under Ar. D: potential/pH dependence of $\mathrm{E} 1 / 2$ for the Rec- $\operatorname{RrCODH}{ }^{\mathrm{CT}}$-functionalized MWCNT electrodes accompanied with linear fit (gray dashed line) and standard $\mathrm{CO} / \mathrm{CO}_{2}$ redox couple $\mathrm{pH}$ dependence (red line).

Compared to the reduction peak current, a higher oxidation peak current indicates the presence of residual catalytic activity from the reduction of dissolved $\mathrm{CO}_{2}$ traces and the oxidation of as-formed $\mathrm{CO}$ at this highly-porous electrodes. $\mathrm{CVs}$ were performed in the presence of $2 \mathrm{mM} \mathrm{NaCN}$ to inhibit the catalytic activity corresponding to $\mathrm{CO}$ oxidation by forming the $\mathrm{C}_{\text {red1 }}-\mathrm{CN}$ adduct. As expected from EPR studies (see above), the oxidation peak current decreases, leaving the response of the electrochemically-irreversible $\mathrm{C}_{\text {red1 }}-\mathrm{CN}$ inactive species. On the contrary, catalytic $\mathrm{CO}_{2}$ reduction do not contribute significantly to the cathodic peak, as confirmed by $\mathrm{CV}$ performed in the presence of $5 \mathrm{mM}$ KOCN (Figure S4). Having confirmed the nonturnover redox signal of the immobilized Rec- $R r \mathrm{CODH}^{\mathrm{CTJ}}$, a surface coverage of $\Gamma_{\mathrm{CODH}}=35(+/-2)$ and $52(+/-2) \mathrm{pmol} \mathrm{cm}^{-2}$ was estimated for MWCNT and MWCNT ${ }^{\mathrm{ADA}}$ electrodes respectively, calculated from the integration of the charge under both the reduction peak or the oxidation peak. For comparison, $\mathrm{NiFeSe}$ hydrogenases from Desulfomicrobium baculatum has also been immobilized on similar MWCNT electrodes with maximum surface coverages in the order of $10 \mathrm{pmol} \mathrm{cm}{ }^{-2}{ }^{36}$
Considering the fact that the amount of MWCNT is approximatively $40 \mu \mathrm{g}$ per electrode, this corresponds to a mass loading of 0.17 and $0.25 \mu \mathrm{g}$ of enzyme per $\mathrm{mg}$ of MWCNT for MWCNT and MWCNT ${ }^{\mathrm{ADA}}$ electrodes respectively. As far as we know, no reversible systems have already been observed on electrodes for $\mathrm{CODH}$, further underlining the excellent direct wiring of Rec- $R r C O D H^{\mathrm{CTJ}}$ on both MWCNT and MWCNT ${ }^{\mathrm{ADA}}$ electrodes.

$\mathrm{Rec}-\operatorname{RrCODH}$ and Rec- $R r C O D \mathrm{H}^{\mathrm{CTJ}}$ were then investigated under $\mathrm{CO}$ and $\mathrm{CO}_{2}$. Figure 4 displays $\mathrm{CV}$ performed in saturated solutions of $\mathrm{CO}$ and $\mathrm{CO}_{2}$ under quiescent conditions for MWCNT and MWCNT ${ }^{\mathrm{ADA}}$ electrodes. Control experiments were also performed on nonfunctionzalized MWCNTs (Figure S5). No redox activity nor electrocatalytic activity towards both $\mathrm{CO}_{2}$ reduction and $\mathrm{CO}$ oxidation were observed.

Under $\mathrm{CO}$, an irreversible oxidation peak with a maximum current density of $0.35 \mathrm{~mA} \mathrm{~cm}^{-2}$ at $-0.3 \mathrm{~V}$ vs. SHE was observed for both MWCNT and MWCNT ${ }^{\mathrm{ADA}}$ respectively. Two main factors are responsible for the fact that electrocatalytic waveshapes exhibit a residual slope instead of reaching a plateau: the diffusion limitations of gas at these highly-porous nanostructured electrode and the presence of a statistical distribution of enzyme orientation immobilized at the surface of the electrode. ${ }^{53437}$ It is important to note that lower current under $\mathrm{CO}$ atmosphere is mostly due to the low solubility of $\mathrm{CO}$ at atmospheric pressure. Furthermore, substrate diffusion limitations are commonly observed at these highly porous MWCNT electrodes. Nonetheless, high electrocatalytic current densities under $\mathrm{CO}_{2}$ of 2.1 and $2.9 \mathrm{~mA} \mathrm{~cm}^{-2}$ at $-0.75 \mathrm{~V}$ vs. SHE was measured for MWCNT and MWCNT ${ }^{\mathrm{ADA}}$ electrodes, respectively.

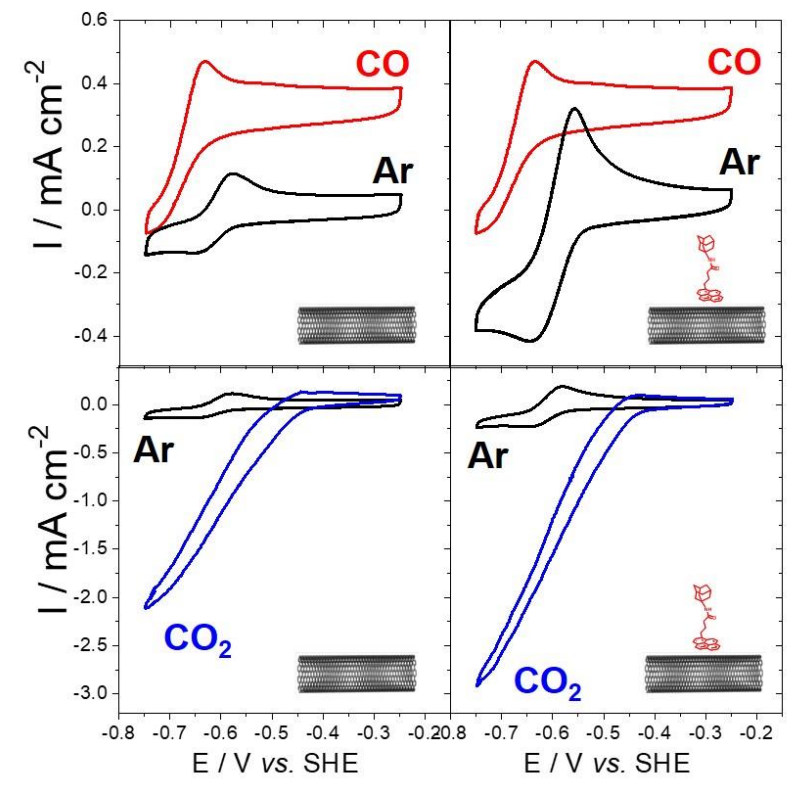

Figure 4. $\mathrm{CV}$ s of the $\mathrm{Rec}-\mathrm{RrCODH} \mathrm{CTJ}^{\mathrm{CT}}$-functionalized (black) pristine MWCNT, (red) MWCNT ${ }^{\mathrm{ADA}}$ electrodes under Ar, CO and $\mathrm{CO}_{2}\left(50 \mathrm{mM}\right.$ Tris- $\left.\mathrm{HCl}, \mathrm{pH} 8.5, \mathrm{v}=5 \mathrm{mV} \mathrm{s}^{-1}\right)$.

Electrocatalytic activities were tested for both Rec-RrCODH and $\mathrm{Rec}-\mathrm{RrCODH}{ }^{\mathrm{CTJ}}$. Higher maximum electrocatalytic currents were observed for $\mathrm{Rec}-\mathrm{RrCODH} \mathrm{H}^{\mathrm{CTJ}}$, as compared to the Rec- $R r C O D H$ which shows 1.2 and $2.1 \mathrm{~mA} \mathrm{~cm}^{-2}$ towards $\mathrm{CO}_{2}$ reduction for MWCNT and $\mathrm{MWCNT}^{\mathrm{ADA}}$ electrodes respectively (Figure S6). This likely accounts for the higher enzymatic 
activity and stability of Rec- $R r C O D H^{\mathrm{CTJ}}$. As expected from surface coverage measurements, MWCNT ${ }^{\mathrm{ADA}}$ electrodes exhibits the highest electrocatalytic activity for $\mathrm{CO}_{2}$ reduction. This is caused by the higher amount of CODH immobilized on these modified MWCNTs. A study of $\operatorname{RrCODH}$ surface hydrophobicity (Figure S7) indicates that the D-cluster is surrounded by two well-defined hydrophobic patches, which may contribute to the enzyme affinity for adamantane, previously shown to interact with proteins via hydrophobic interactions. ${ }^{36}$ In this regard, adamantane would play a significant role in the enzyme immobilization and orientation, explaining the improvement of Rec$\operatorname{RrCODH}{ }^{\mathrm{CTJ}}$-functionalized MWCNT ${ }^{\mathrm{ADA}}$ activity.

$\mathrm{pH}$ dependence measurements were performed and showed that the immobilized enzyme follows the trend of the enzyme in solution, showing the best performances above $\mathrm{pH} 8.5$ reaching maximum current densities of $3.15 \mathrm{~mA} \mathrm{~cm}^{-2}$ at $\mathrm{pH} 9.5$ (Figure S8) Chronoamperometric measurements were performed to estimate the operating stability and the Turnover Number (TON) of the immobilized Rec-RrCODH ${ }^{\mathrm{CTJ}}$. TON was measured by integration of the total charge passed during the chronoamperometry taking into account the estimated enzyme surface coverage. A TON of 800,000 was measured by a one-hour chronoamperometry (Figure S9) performed at a fixed potential of $-0.75 \mathrm{~V}$ vs SHE (overpotential of $0.13 \mathrm{~V}$ ). This corresponds to an average TOF of $224 \mathrm{~s}^{-1}$ over one hour. TOF value was calculated using the equation $\mathrm{TOF}=\mathrm{I}_{\mathrm{MAX}} /\left(2 \mathrm{xFx} \Gamma_{\mathrm{CODH}}\right)$. A partial deactivation after one hour $(35 \%)$ likely arises from a leaking of loosely-adsorbed $\mathrm{CODH}$ or the presence of $\mathrm{O}_{2}$ traces in $\mathrm{CO}_{2}$ gas bottle (10 ppm).

\section{$\mathrm{CO}_{2} / \mathrm{CO}$ interconversions in Gas-diffusion bioelectrodes}

In order to optimize the electrocatalytic performances of these bioelectrodes as well as to test their ability to operate in a functional device, a specific gas-diffusion electrode was designed allowing the constant flow of $\mathrm{CO}$ or $\mathrm{CO}_{2}$ at $\mathrm{CODH}$-modified gas-diffusion MWCNT electrode. This type of electrode allows the (bio)catalyst to operate at a three-phase boundary, circumventing gas substrate solubility and diffusion issues. This is especially challenging for enzymes which requires the presence of a surrounding buffer solution with optimal pH. ${ }^{34} 363755$ A MWCNT film was deposited at the surface of a microporous gas-diffusion layer and subsequently modified with 1Pyrenebutyric acid adamantyl amide and RecRrCODH ${ }^{\mathrm{CTJ}}$ (Figure $5 \mathrm{~A}$ and $5 \mathrm{~B}$ ). A graphite plate with a serpentine flow design ensures a homogenous gas flow at the back of the bioelectrode where the enzyme is in contact with a degassed $50 \mathrm{mM}$ Tris$\mathrm{HCl} \mathrm{pH}$ 8.5. Laser scanning microscopy (LSM) measurements were performed showing a homogenous MWCNT film with an average thickness of $3 \mu \mathrm{M}$ on the microporous layer (Figure S10A,B). Scanning Electron Microscopy of the surface of the electrode underlines the high porosity of these functionalized bioelectrodes (Figure S10C). CVs were performed with a constant flow of $\mathrm{CO}, \mathrm{CO}_{2}$ or $\mathrm{Ar}$ (Figure 5C). Owing to the gasdiffusion electrode, electrocatalytic current densities for $\mathrm{CO}$ oxidation reaches current density of $1.5 \mathrm{~mA}$ at $-0.38 \mathrm{~V}$ while maximum current densities for $\mathrm{CO}_{2}$ reaches $4.2 \mathrm{~mA} \mathrm{~cm}^{-2}$ at $-0.8 \mathrm{~V}$. This corresponds to TOF values of $420 \mathrm{~s}^{-1}$ for $\mathrm{CO}_{2}$ reduction at $180 \mathrm{mV}$ overpotential and $150 \mathrm{~s}^{-1}$ for CO oxidation at $250 \mathrm{mV}$ overpotential. Comparing gas-diffusion electrode performances with previous experiments with solubilized gas, an increase in terms of current density is observed for both $\mathrm{CO}$ oxidation and
$\mathrm{CO}_{2}$ reduction. While $\mathrm{CO}$ oxidation is mostly limited by low $\mathrm{CO}$ solubility in solution, both catalyst loadings and substrate diffusion are the limiting factors at these porous 3D MWCNT films for gas-diffusion electrode experiments.

The products of the electrocatalysis were analyzed by gas chromatography. As expected, the immobilized enzyme produces $100 \% \mathrm{CO}$ from $\mathrm{CO}_{2}$ reduction and $100 \% \mathrm{CO}_{2}$ from $\mathrm{CO}$ oxidation, either at MWCNT-modified GC electrodes or at gas-diffusion MWCNT electrodes. (Figure S11).

For comparison, the state-of-the-art performances for molecular-based catalysts towards $\mathrm{CO}_{2}$-to- $\mathrm{CO}$ conversion have been reported for CNT-modified azamacrocycle cobalt complexes. ${ }^{56,57,58}$ A cobalt quaterpyridine hybrid catalyst reaches $19.9 \mathrm{~mA} \mathrm{~cm}^{-2}$ at overpotential of $440 \mathrm{mV}$ with catalyst loading of $8.5 \mathrm{nmol} \mathrm{cm} \mathrm{cm}^{-2}$, TOF of $12 \mathrm{~s}^{-1}$ and maximum estimated TON of 89095 .
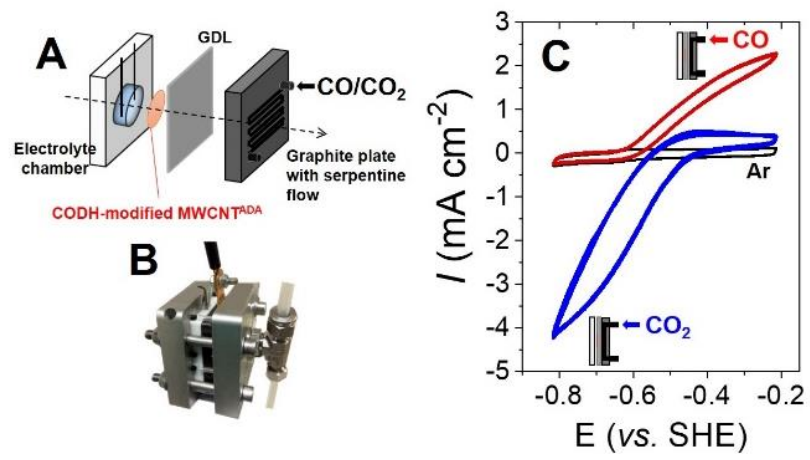

Figure 5. A: Schematic representation and B: photograph of the gas-diffusion electrochemical. C: CVs (three cycles) of the Rec$\operatorname{RrCODH}{ }^{\mathrm{CTJ}}$-functionalized MWCNT ${ }^{\mathrm{ADA}}$ gas-diffusion bioelectrodes under $\mathrm{Ar}, \mathrm{CO}$ and $\mathrm{CO}_{2}(50 \mathrm{mM}$ Tris- $\mathrm{HCl}, \mathrm{pH} 8.5, \mathrm{v}=5 \mathrm{mV}$ $\left.\mathrm{s}^{-1}\right)$.

This work represents the first example of a CODH-based electrode working at a gas-diffusion electrode. For comparison, the only other $\mathrm{CODH}$ studied at nanostructured electrode towards electrocatalytic $\mathrm{CO}_{2}$ reduction is $\mathrm{ChCODH}-\mathrm{I}$ which was immobilized at nanostructured silver-nanocluster-modified $\mathrm{TiO}_{2}$ electrodes and achieved maximum current density of $0.26 \mathrm{~mA}$ $\mathrm{cm}^{-2} .^{12}$ Other types of metal-based nanomaterials such as CNTsupported copper phtalocyanines ${ }^{59}$ reaches $6.9 \mathrm{~mA} \mathrm{~cm}^{-2}$ at 300 $\mathrm{mV}$ overpotential while, in the case of mesoporous gold-based electrodes, ${ }^{60} 22 \mathrm{~mA} \mathrm{~cm}^{-2}$ can be reached at $240 \mathrm{mV}$ overpotential. These results show that Rec- $\operatorname{RrCODH} \mathrm{CTJ}^{\mathrm{CT}}$-modified MWCNT $^{\mathrm{ADA}}$ electrodes are closed to the best metal-based and molecular-based catalysts in terms of current densities. In addition, Rec- $\operatorname{RrCODH}$-modified MWCNT ${ }^{\mathrm{ADA}}$ outperforms stateof-the-art catalysts for $\mathrm{CO}_{2}$ to $\mathrm{CO}$ reduction in terms of overpotential and exhibits higher TON values as compared to molecular catalysts for $\mathrm{CO}_{2}$ reduction (Table $\mathrm{S} 1$ ).

\section{Conclusion}

The design of efficient electrocatalysts holds the promise to offer new attractive strategies in sustainable energy. In this field, anaerobic gas-processing metalloenzymes suffer from their complexity and stability. However, bio-electrocatalysis affords several advantages such as highly selective catalytic efficiencies under mild conditions ( $\mathrm{pH}$, temperature, aqueous solvent, ...) at low overpotentials and using non-noble metals. In this 
study, the easy production of a stable and fully active recombinant $R r C O D H$ with a $\mathrm{CO}$ oxidation activity reaching up to $26,500 \mathrm{U} \cdot \mathrm{mg}^{-1}$ in solution makes it an interesting candidate for future applications. The electrocatalytic activity of Rec $\operatorname{RrCODH}{ }^{\mathrm{CT}}$-immobilized MWCNT $^{\mathrm{ADA}}$ electrodes for $\mathrm{CO} / \mathrm{CO}_{2}$ interconversion, either in classic three-electrode cell or in specifically-designed $\mathrm{CO}_{2} / \mathrm{CO}$-diffusing electrodes surpasses those reported earlier, when graphite or $\mathrm{TiO}_{2}$ was used. Remarkably, the high performances of Rec- $R r C O D H^{\mathrm{CTJ}}$-modified MWCNT $^{\mathrm{ADA}}$ are fully demonstrated, with a stability over several hours with at least 800000 turnovers. Its competitiveness with molecular-based catalysts used in electrochemical $\mathrm{CO}_{2}$ reduction paves the way for the development of new functional enzymatic devices. Furthermore, taking into account the high sensitivity of these enzymes towards oxygen, oxygen deactivation has to be tackled, through diverse approaches such as specific electrode engineering, ${ }^{553661}$ the screening of CODH biodiversity, site-directed mutagenesis ${ }^{12}$ or enzyme immobilisation. Furthermore, the ability of Rec- $R r C O D H^{\mathrm{CTJ}}$ to, reversibly, oxidize $\mathrm{CO}$ at low overpotentials with similar high electrocatalytic activity in mild conditions makes this type of biofunctionalized nanostructured electrode a potent catalyst for applications such as WGSR.

\section{Associated content}

\section{Supporting Information.}

Methods: cloning, enzyme production, purification and characterization, EPR, electrochemistry, preparation and functionalization of MWCNT. "This material is available free of charge via the Internet at http://pubs.acs.org."

\section{Author Information}

\section{Corresponding Authors}

christine.cavazza@cea.fr; alan.le-goff@univ-grenoble-alpes.fr

\section{Funding Sources}

This work was supported by the Agence Nationale de la Recherche through the LabEx ARCANE program (ANR-11LABX-0003-01) and the Graduate School on Chemistry, Biology and Health of Univ Grenoble Alpes CBH-EUR-GS (ANR17-EURE-0003). The authors acknowledge support from the plateforme de Chimie NanoBio ICMG FR 2607 (PCN-ICMG). This work has been partially funded by CNRS via « Mission pour les Initiatives Transverses et Interdisciplinaires (MITI) » and «Cellule Energie » of CNRS through the project «EGreenSyn».

\section{Acknowledgment}

The authors are grateful to the EPR facilities available at the French EPR network (RENARD, IR CNRS 3443) and the AixMarseille University EPR center. The authors acknowledge support from the plateforme de Chimie NanoBio ICMG FR 2607 (PCN-ICMG). The authors also thank Gregory Cwicklinski for his help for GC measurements.

\section{References}

(1)

Drennan, C. L.; Heo, J.; Sintchak, M. D.; Schreiter, E.; Ludden, P. W. Life on Carbon Monoxide: X-Ray Structure of Rhodospirillum Rubrum Ni-Fe-S Carbon Monoxide Dehydrogenase. Proc. Natl. Acad. Sci. U. S. A. 2001, 98 (21), 11973-11978.
Dobbek, H.; Svetlitchnyi, V.; Gremer, L.; Huber, R.; Meyer, O. Crystal Structure of a Carbon Monoxide Dehydrogenase Reveals a [Ni-4Fe-5S] Cluster. Science (80-. ). 2001, 293 (5533), 12811285 .

(3) Jeoung, J. H.; Martins, B. M.; Dobbek, H. Carbon Monoxide Dehydrogenases. Methods Mol. Biol. 2019, 1876, 37-54.

(4) Can, M.; Armstrong, F. A.; Ragsdale, S. W. Structure, Function, and Mechanism of the Nickel Metalloenzymes, CO Dehydrogenase, and Acetyl-CoA Synthase. Chem. Rev. 2014, 114 (8), 4149-4174.

(5) Breglia, R.; Arrigoni, F.; Sensi, M.; Greco, C.; Fantucci, P.; De Gioia, L.; Bruschi, M. First-Principles Calculations on Ni,FeContaining Carbon Monoxide Dehydrogenases Reveal Key Stereoelectronic Features for Binding and Release of $\mathrm{CO} 2$ to/from the C-Cluster. Inorg. Chem. 2021, 60 (1), 387-402.

Wang, V. C.-C.; Can, M.; Pierce, E.; Ragsdale, S. W.; Armstrong, F. A. A Unified Electrocatalytic Description of the Action of Inhibitors of Nickel Carbon Monoxide Dehydrogenase. J. Am. Chem. Soc. 2013, 135 (6), 2198-2206.

(7) Wang, V. C.-C.; Islam, S. T. A.; Can, M.; Ragsdale, S. W.; Armstrong, F. A. Investigations by Protein Film Electrochemistry of Alternative Reactions of Nickel-Containing Carbon Monoxide Dehydrogenase. J. Phys. Chem. B 2015, 119 (43), 13690-13697.

(8) Wang, V. C.-C.; Ragsdale, S. W.; Armstrong, F. A. Investigations of Two Bidirectional Carbon Monoxide Dehydrogenases from Carboxydothermus Hydrogenoformans by Protein Film Electrochemistry. ChemBioChem 2013, 14 (14), 1845-1851.

Parkin, A.; Seravalli, J.; Vincent, K. A.; Ragsdale, S. W.; Armstrong, F. A. Rapid and Efficient Electrocatalytic CO2/CO Interconversions by Carboxydothermus Hydrogenoformans $\mathrm{CO}$ Dehydrogenase I on an Electrode. J. Am. Chem. Soc. 2007, 129 (34), 10328-10329.

(10) Domnik, L.; Merrouch, M.; Goetzl, S.; Jeoung, J.-H.; Léger, C.; Dementin, S.; Fourmond, V.; Dobbek, H. CODH-IV: A HighEfficiency CO-Scavenging CO Dehydrogenase with Resistance to O2. Angew. Chemie Int. Ed. 2017, 56 (48), 15466-15469.

Merrouch, M.; Hadj-Saïd, J.; Domnik, L.; Dobbek, H.; Léger, C.; Dementin, S.; Fourmond, V. O2 Inhibition of Ni-Containing CO Dehydrogenase Is Partly Reversible. Chem. - A Eur. J. 2015, 21 (52), 18934-18938.

(12) Wittenborn, E. C.; Guendon, C.; Merrouch, M.; Benvenuti, M.; Fourmond, V.; Léger, C.; Drennan, C. L.; Dementin, S. The Solvent-Exposed $\mathrm{Fe}-\mathrm{S}$ D-Cluster Contributes to OxygenResistance in Desulfovibrio Vulgaris Ni-Fe Carbon Monoxide Dehydrogenase. ACS Catal. 2020, 10 (13), 7328-7335.

(13) Zhang, L.; Can, M.; Ragsdale, S. W.; Armstrong, F. A. Fast and Selective Photoreduction of CO2 to CO Catalyzed by a Complex of Carbon Monoxide Dehydrogenase, $\mathrm{TiO} 2$, and $\mathrm{Ag}$ Nanoclusters. ACS Catal. 2018, 8 (4), 2789-2795.

(14) Lazarus, O.; Woolerton, T. W.; Parkin, A.; Lukey, M. J.; Reisner, E.; Seravalli, J.; Pierce, E.; Ragsdale, S. W.; Sargent, F.; Armstrong, F. A. Water-Gas Shift Reaction Catalyzed by Redox Enzymes on Conducting Graphite Platelets. J. Am. Chem. Soc. 2009, 131 (40), 14154-14155.

(15) Robb, F. T.; Techtmann, S. M. Life on the Fringe: Microbial Adaptation to Growth on Carbon Monoxide. F1000Research 2018, 7, F1000 Faculty Rev-1981.

(16) Kerby, R. L.; Ludden, P. W.; Roberts, G. P. Carbon MonoxideDependent Growth of Rhodospirillum Rubrum. J. Bacteriol. 1995, 177 (8), 2241-2244.

(17) Alfano, M.; Cavazza, C. Structure, Function, and Biosynthesis of Nickel-Dependent Enzymes. Protein Sci. 2020, 29 (5), 10711089 .

(18) Wu, M.; Ren, Q.; Scott Durkin, A.; Daugherty, S. C.; Brinkac, L. M.; Dodson, R. J.; Madupu, R.; Sullivan, S. A.; Kolonay, J. F.; Nelson, W. C.; Tallon, L. J.; Jones, K. M.; Ulrich, L. E.; Gonzalez, J. M.; Zhulin, I. B.; Robb, F. T.; Eisen, J. A. Life in Hot Carbon Monoxide: The Complete Genome Sequence of Carboxydothermus Hydrogenoformans Z-2901. PLoS Genet. 2005, 1 (5), 563-574.

(19) Jeoung, J.-H.; Dobbek, H. Carbon Dioxide Activation at the $\mathrm{Ni}, \mathrm{Fe}-\mathrm{Cluster}$ of Anaerobic Carbon Monoxide Dehydrogenase. Science (80-. ). 2007, 318 (5855), 1461-1464. 

265 in Carbon Monoxide Dehydrogenase from Rhodospirillum Rubrum Affects Activity and Spectroscopic States. J. Biol. Chem. 1998, 273 (7), 4059-4064.

(21) Craft, J. L.; Ludden, P. W.; Brunold, T. C. Spectroscopic Studies of Nickel-Deficient Carbon Monoxide Dehydrogenase from Rhodospirillum Rubrum: Nature of the Iron-Sulfur Clusters. Biochemistry 2002, 41 (5), 1681-1688.

(22) Bonam, D.; Ludden, P. W. Purification and Characterization of Carbon Monoxide Dehydrogenase, a Nickel, Zinc, Iron-Sulfur Protein, from Rhodospirillum Rubrum. J. Biol. Chem. 1987, 262 (7), 2980-2987.

(23) Jeon, W. B.; Singer, S. W.; Ludden, P. W.; Rubio, L. M. New Insights into the Mechanism of Nickel Insertion into Carbon Monoxide Dehydrogenase: Analysis of Rhodospirillum Rubrum Carbon Monoxide Dehydrogenase Variants with Substituted Ligands to the [Fe3S4] Portion of the Active-Site C-Cluster. JBIC J. Biol. Inorg. Chem. 2005, 10 (8), 903-912.

(24) Alfano, M.; Cavazza, C. The Biologically Mediated Water-gas Shift Reaction: Structure\{,\} Function and Biosynthesis of Monofunctional [NiFe]-Carbon Monoxide Dehydrogenases. Sustain. Energy Fuels 2018, 2 (8), 1653-1670.

(25) Singer, S. W.; Hirst, M. B.; Ludden, P. W. CO-Dependent H2 Evolution by Rhodospirillum Rubrum: Role of CODH:CooF Complex. Biochim. Biophys. Acta 2006, 1757 (12), 1582-1591.

(26) Jeon, W. B.; Cheng, J.; Ludden, P. W. Purification and Characterization of Membrane-Associated CooC Protein and Its Functional Role in the Insertion of Nickel into Carbon Monoxide Dehydrogenase from Rhodospirillum Rubrum *. 2001, 276 (42), 38602-38609.

(27) Alfano, M.; Veronesi, G.; Musiani, F.; Zambelli, B.; Signor, L. Supporting Information A Solvent-Exposed Cysteine Forms a Peculiar Ni II -Binding Site in the Metallochaperone CooT from Rhodospirillum Rubrum.

(28) Alfano, M.; Pérard, J.; Cavazza, C. Nickel-Induced Oligomerization of the Histidine-Rich Metallochaperone CooJ from Rhodospirillum Rubrum. Inorganics 2019, 7, 84.

(29) Alfano, M.; Pérard, J.; Carpentier, P.; Basset, C.; Zambelli, B.; Timm, J.; Crouzy, S.; Ciurli, S.; Cavazza, C. The Carbon Monoxide Dehydrogenase Accessory Protein CooJ Is a HistidineRich Multidomain Dimer Containing an Unexpected Ni(II)Binding Site. J. Biol. Chem. 2019, 294 (19), 7601-7614.

(30) Timm, J.; Brochier-Armanet, C.; Perard, J.; Zambelli, B.; Ollagnier-de-Choudens, S.; Ciurli, S.; Cavazza, C. The CO Dehydrogenase Accessory Protein CooT Is a Novel NickelBinding Protein. Metallomics 2017, 9 (5), 575-583.

(31) Kerby, R. L.; Ludden, P. W.; Roberts, G. P. In Vivo Nickel Insertion into the Carbon Monoxide Dehydrogenase of Rhodospirillum Rubrum: Molecular and Physiological Characterization of CooCTJ. J. Bacteriol. 1997, 179 (7), 22592266.

(32) Ensign, S. A.; Campbell, M. J.; Ludden, P. W. Activation of the Nickel-Deficient Carbon Monoxide Dehydrogenase from Rhodospirillum Rubrum: Kinetic Characterization and Reductant Requirement. Biochemistry 1990, 29 (8), 2162-2168.

(33) Le Goff, A.; Holzinger, M. Molecular Engineering of the Bio/Nano-Interface for Enzymatic Electrocatalysis in Fuel Cells. Sustain. Energy Fuels 2018, 2 (12), 2555-2566.

(34) Lau, C.; Adkins, E. R.; Ramasamy, R. P.; Luckarift, H. R.; Johnson, G. R.; Atanassov, P. Design of Carbon Nanotube-Based Gas-Diffusion Cathode for O2 Reduction by Multicopper Oxidases. Adv. Energy Mater. 2012, 2 (1), 162-168.

(35) Meredith, M. T.; Minson, M.; Hickey, D.; Artyushkova, K.; Glatzhofer, D. T.; Minteer, S. D. Anthracene-Modified MultiWalled Carbon Nanotubes as Direct Electron Transfer Scaffolds for Enzymatic Oxygen Reduction. ACS Catal. 2011, 1 (12), 1683-1690.

(36) Gentil, S.; Che Mansor, S. M.; Jamet, H.; Cosnier, S.; Cavazza, C.; Le Goff, A. Oriented Immobilization of [NiFeSe] Hydrogenases on Covalently and Noncovalently Functionalized Carbon Nanotubes for H2/Air Enzymatic Fuel Cells. ACS Catal. 2018, 8 (5), 3957-3964.

Gentil, S.; Lalaoui, N.; Dutta, A.; Nedellec, Y.; Cosnier, S.; Shaw, W. J.; Artero, V.; Le Goff, A. Carbon-Nanotube-Supported BioInspired Nickel Catalyst and Its Integration in Hybrid Hydrogen/Air Fuel Cells. Angew. Chemie Int. Ed. 2017, 56 (7), 1845-1849.

(38) Ensign, S. A.; Bonam, D.; Ludden, P. W. Nickel Is Required for the Transfer of Electrons from Carbon Monoxide to the IronSulfur Center(s) of Carbon Monoxide Dehydrogenase from Rhodospirillum Rubrum. Biochemistry 1989, 28 (12), 49684973.

(39) Inoue, T.; Takao, K.; Fukuyama, Y.; Yoshida, T.; Sako, Y. OverExpression of Carbon Monoxide Dehydrogenase-I with an Accessory Protein Co-Expression: A Key Enzyme for Carbon Dioxide Reduction. Biosci. Biotechnol. Biochem. 2014, 78 (4), $582-587$.

(40) Fontecave, M.; Py, B.; Ollagnier de Choudens, S.; Barras, F. From Iron and Cysteine to Iron-Sulfur Clusters: The Biogenesis Protein Machineries. EcoSal Plus 2008, 3 (1).

(41) Ensign, S. A.; Ludden, P. W. Characterization of the CO Oxidation/H2 Evolution System of Rhodospirillum Rubrum: Role of a 22-KDa Iron-Sulfur Protein in Mediating Electron Transfer between Carbon Monoxide Dehydrogenase and Hydrogenase. J. Biol. Chem. 1991, 266 (27), 18395-18403.

(42) Svetlitchnyi, V.; Peschel, C.; Acker, G.; Meyer, O. Two Membrane-Associated NiFeS-Carbon Monoxide Dehydrogenases from the Anaerobic Carbon-Monoxide-Utilizing Eubacterium Carboxydothermus Hydrogenoformans. J. Bacteriol. 2001, 183 (17), 5134-5144.

(43) Benvenuti, M.; Meneghello, M.; Guendon, C.; Jacq-Bailly, A.; Jeoung, J. H.; Dobbek, H.; Léger, C.; Fourmond, V.; Dementin, S. The Two CO-Dehydrogenases of Thermococcus Sp. AM4. Biochim. Biophys. Acta - Bioenerg. 2020, 1861 (7).

(44) Hadj-Saïd, J.; Pandelia, M. E.; Léger, C.; Fourmond, V.; Dementin, S. The Carbon Monoxide Dehydrogenase from Desulfovibrio Vulgaris. Biochim. Biophys. Acta - Bioenerg. 2015, 1847 (12), 1574-1583.

(45) Wittenborn, E. C.; Merrouch, M.; Ueda, C.; Fradale, L.; Léger, C.; Fourmond, V.; Pandelia, M.-E.; Dementin, S.; Drennan, C. L. Redox-Dependent Rearrangements of the NiFeS Cluster of Carbon Monoxide Dehydrogenase. Elife 2018, 7.

(46) Hu, Z.; Spangler, N. J.; Anderson, M. E.; Xia, J.; Ludden, P. W.; Lindahl, P. A.; Münck, E. Nature of the C-Cluster in NiContaining Carbon Monoxide Dehydrogenases. J. Am. Chem. Soc. 1996, 118 (4), 830-845.

(47) Spangler, N. J.; Lindahl, P. A.; Bandarian, V.; Ludden, P. W. Spectroelectrochemical Characterization of the Metal Centers in Carbon Monoxide Dehydrogenase (CODH) and Nickel-Deficient CODH from Rhodospirillum Rubrum. J. Biol. Chem. 1996, 271 (14), 7973-7977.

(48) Guigliarelli, B.; Guillaussier, J.; More, C.; Sétif, P.; Bottin, H.; Bertrand, P. Structural Organization of the Iron-Sulfur Centers in Synechocystis 6803 Photosystem I: EPR Study of Oriented Thylakoid Membranes and Analysis of the Magnetic Interactions. J. Biol. Chem. 1993, 268, 900-908.

(49) Bertrand, P.; Camensuli, P.; More, C.; Guigliarelli, B. A Local Spin Model To Describe the Magnetic Interactions in Biological Molecules Containing [4Fe-4S]+Clusters. Application to $\mathrm{Ni}-\mathrm{Fe}$ Hydrogenases. J. Am. Chem. Soc. 1996, 118 (6), 1426-1434.

(50) Anderson, M. E.; DeRose, V. J.; Hoffman, B. M.; Lindahl, P. A. Identification of a Cyanide Binding Site in CO Dehydrogenase from Clostridium Thermoaceticum Using EPR and ENDOR Spectroscopies. J. Am. Chem. Soc. 1993, 115 (25), 12204-12205.

(51) Lalaoui, N.; David, R.; Jamet, H.; Holzinger, M.; Le Goff, A.; Cosnier, S. Hosting Adamantane in the Substrate Pocket of Laccase: Direct Bioelectrocatalytic Reduction of $\mathrm{O} 2$ on Functionalized Carbon Nanotubes. ACS Catal. 2016, 6 (7), 42594264.

(52) Bard, A. J.; Faulkner, L. R. Electrochemical Methods: Fundamentals and Applications.; Wiley-VCH Verlag GmbH \& Co. KGaA, 2001.

(53) Leger, C.; Jones, A. K.; Albracht, S. P. J.; Armstrong, F. A. Effect of a Dispersion of Interfacial Electron Transfer Rates on Steady State Catalytic Electron Transport in [NiFe]-Hydrogenase and 
Other Enzymes. J. Phys. Chem. B 2002, 106 (50), 13058-13063. Lalaoui, N.; Le Goff, A.; Holzinger, M.; Cosnier, S. Fully Oriented Bilirubin Oxidase on Porphyrin-Functionalized Carbon Nanotube Electrodes for Electrocatalytic Oxygen Reduction. Chem. - A Eur. J. 2015, 21 (47), 16868-16873. Lalaoui, N.; de Poulpiquet, A.; Haddad, R.; Le Goff, A.; Holzinger, M.; Gounel, S.; Mermoux, M.; Infossi, P.; Mano, N.; Lojou, E.; Cosnier, S. A Membraneless Air-Breathing Hydrogen Biofuel Cell Based on Direct Wiring of Thermostable Enzymes on Carbon Nanotube Electrodes. Chem. Commun. 2015, 51 (35), $7447-7450$

(56) Wang, M.; Chen, L.; Lau, T.-C.; Robert, M. A Hybrid Co Quaterpyridine Complex/Carbon Nanotube Catalytic Material for CO2 Reduction in Water. Angew. Chemie Int. Ed. 2018, 57 (26), 7769-7773.

(57) Zhang, X.; Wu, Z.; Zhang, X.; Li, L.; Li, Y.; Xu, H.; Li, X.; Yu, X.; Zhang, Z.; Liang, Y.; Wang, H. Highly Selective and Active $\mathrm{CO} 2$ Reduction Electrocatalysts Based on Cobalt Phthalocyanine/Carbon Nanotube Hybrid Structures. Nat. Commun. 2017, 8 (1), 14675.
(58) Wang, X.; Libo, S.; Huang, Z.; Reddu, V.; Su, T.; Fisher, A. A Planar, Conjugated N4 -Macrocyclic Cobalt Complex for Heterogeneous Electrocatalytic CO2 Reduction with High Activity. Angew. Chemie Int. Ed. 2020.

(59) Karapinar, D.; Zitolo, A.; Huan, T. N.; Zanna, S.; Taverna, D.; Galvão Tizei, L. H.; Giaume, D.; Marcus, P.; Mougel, V.; Fontecave, M. Carbon-Nanotube-Supported Copper Polyphthalocyanine for Efficient and Selective Electrocatalytic CO2 Reduction to CO. ChemSusChem 2020, 13 (1), 173-179.

(60) Liu, M.; Pang, Y.; Zhang, B.; De Luna, P.; Voznyy, O.; Xu, J.; Zheng, X.; Dinh, C. T.; Fan, F.; Cao, C.; de Arquer, F. P. G.; Safaei, T. S.; Mepham, A.; Klinkova, A.; Kumacheva, E.; Filleter, T.; Sinton, D.; Kelley, S. O.; Sargent, E. H. Enhanced Electrocatalytic $\mathrm{CO} 2$ Reduction via Field-Induced Reagent Concentration. Nature 2016, 537 (7620), 382-386.

(61) Plumeré, N.; Rüdiger, O.; Oughli, A. A.; Williams, R.; Vivekananthan, J.; Pöller, S.; Schuhmann, W.; Lubitz, W. A Redox Hydrogel Protects Hydrogenase from High-Potential Deactivation and Oxygen Damage. Nat. Chem. 2014, 6 (9), 822 827. 